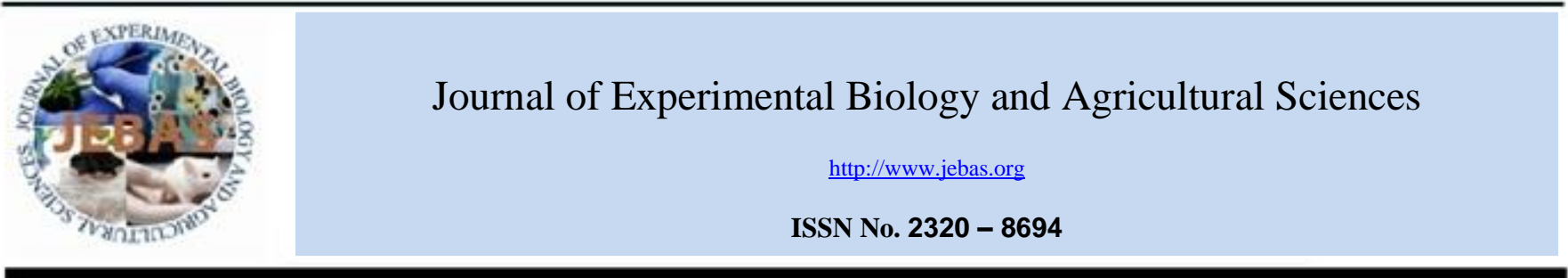

\title{
A NEW SPECIES OF Acremoniula G. ARNAUD EX CIF. ON Butea Monosperma (LAM.) TAUB. - AN IMPORTANT MEDICINAL PLANT FROM FOREST FLORA OF JASHPUR (C.G.)
}

\section{Anurag Dubey*, Smriti Bhardwaj, Atul Kumar Pandey, Anshu Deep Khalkho, Shikha Jain, Akhilanand Rai}

Department of Botany, School of Biological Sciences, Dr. Harisingh Gour Central University, Sagar, M.P., India, 470003

Received - September 28, 2019; Revision - November 03, 2019; Accepted - November 29, 2019

Available Online - December 25, 2019

DOI: http://dx.doi.org/10.18006/2019.7(6).600.605

\section{KEYWORDS}

Acremoniula monospermae

Butea monosperma

Parasite

New taxon

Novel species

\begin{abstract}
The present study was undertaken from the month of September 2016 to December 2018 in Jashpur (C.G.), India to collect infected plant samples. The forest of Jashpur district of Chattisgarh, India possesses great diversity of plants and its pathogenic fungi because of most favourable climatic conditions. Although forest area of Jashpur is almost untouched for forest wealth being most interior part heavily inhabited by tribal people and wild animals; therefore drew less attention towards this branch of study. Hence, intensive and extensive explorations of pathogenic fungi causing disease in plants are necessary and urgent need of time also. The field survey of Jashpur (C.G.) has resulted in the collection of a novel undescribed fungal form i.e. Acremoniula monospermae sp. nov. causing foliar disease of Butea monosperma (Lam.) Taub. Only seven species of Acremoniula G. Arnaud ex Ciferri has been reported so far from all over world as a hyperparasites (overgrowing and parasitic on other fungal organism) or saprophytes (grow on dead and decay matter) but this novel species is reported distinctly as parasites (grow on living leaves of Butea monosperma plant (Lam.) Taub.) and thus another new addition in genus Acremoniula G. Arnaud ex Ciferri.
\end{abstract}

* Corresponding author

E-mail: anu15011991@gmail.com (Anurag Dubey)

Peer review under responsibility of Journal of Experimental Biology and Agricultural Sciences.

Production and Hosting by Horizon Publisher India [HPI] (http://www.horizonpublisherindia.in/).

All rights reserved.
All the articles published by Journal of Experimental Biology and Agricultural Sciences are licensed under a Creative Commons Attribution-NonCommercial 4.0 International License Based on a work at www.jebas.org.

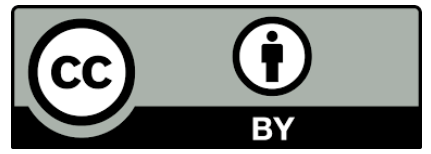




\section{Introduction}

The plants are gem stones of the earth and play very important role in our existence. They fulfill our basic requirements (food, medicines, timber, shelter etc.) and help in balancing our ecosystem. The forest of Jashpur (C.G.), India is very dense because of prolonged moisture, most favorable temperature, rainfall and also other factors suitable for growth and development of the plants and also other numerous fungi. During the field survey of Jashpur forest foliar disease was found on medicinally important plant Butea monosperma (Lam.) Taub. also known as Bastard teak in English while Palash, Tesu and Dhak in Hindi. B. monosperma is 12 metre tall small tree of host family Fabaceae (formerly Leguminosae) and its roots, stem, leaves, flowers and seeds have great importance in traditional medicine (Vaidya \& Pandita, 2017). This plant possesses anti-hepatotoxic, anti-gout, antidiabetic, anti-leprotic, anti-convulsant, anti-microbial, anti-stress, antioxidant, anti-diarrheal, anti-inflammatory and many more properties (Khatak et al., 2019). Pharmacologically, aqueous extract of plant leaves have anti-filarial activity (Sahare et al., 2008) while aqueous extract of flowers possess anti-cancer activity (Choedon et al., 2010), ethanolic extract of stem have potential anti-diarrheal activity (Tiwari et al., 2019) and methanolic extract of plant seeds exhibit anti-fertility effect (Tiwari \& Sahu, 2017). Different parts of this plant are utilized by tribes inhabited in Jashpur (C.G.) forest, they used this tree as food, fodder and medicine. Tribal populations make food plates from its leaves and earning little money for their bread and butter but unfortunately the plant is infected in between the month of July to December every year. The plants shed their leaves as the flowers develop in the month of January to March (Kapoor, 2005; Das et al., 2011), therefore, leaves are of use for very short duration of time. Hence there is great demand to explore untouched area and protect our forest wealth from pathogen in which the fungal biosystematics (mycotaxonomy) plays very important role because details of pathogen is primarily dependent on correct identification of organism. Therefore present study was conducted to explore the fungal pathogens causing leaf spot disease on B. monosperma and disease causing agent was identified with the help of mycotaxonomy and SEM image analysis.

\section{Materials and Methods}

The infected plant samples were collected from Jashpur (C.G.) during field survey in the month of December 2018. At the time of sample collection field notes were made regarding nature of infection, nature of colony (symptomatology), date of collection and locality of collection (Mall \& Kumar, 2014; Sabeena et al., 2018). Infected leaves were collected in neat and clean polythene bags and brought to the mycological laboratory of the department after the field visit is over. Infected samples were dried and pressed carefully with the help of blotting papers (Sabeena et al., 2018). Transfer of collected materials to the fresh and dry blotters at regular intervals ensured complete dryness of the collection (Thomas et al., 2013). Dry and pressed materials are kept in adsorbent paper envelopes along with collection details (Awasthi et al., 2016). Morphological observations of superficial fungi were made after scraping and hand cut sections in lactophenol cotton blue mixture from the infected area of fresh collection (Awasthi et al., 2015). Olympus CX21i trinocular microscope was used for observations at 40x magnification. SEM images were prepared at Central Instrumentation Laboratory (CIL) of Dr. Harisingh Gour Central University, Sagar, M.P., India. Specimen were coated with gold-palladium and examined with a double beam FEI Nova nano SEM-450. MICAPS PROCMOS310CA digital camera was used for dimensions of conidiophores and conidia. The holotype is deposited in Ajrekar Mycological Herbarium (AMH) of Agharkar Research Institute (ARI) for accession number and it's isotype has been kept in Mycological Herbarium of the Department, Dr. Harisingh Gour Central University, Sagar, M.P., India.

\section{Results}

Based on hyaline conidiophores with monoblastic terminal conidiogenus cell and 0 septate, dark brown to black, truncate conidial base this fungus was identified as species of genus Acremoniula G. Arnaud ex Ciferri.

\subsection{Taxonomy and Description}

Acremoniula monospermae A. Dubey, S. Bhardwaj, A.K. Pandey, A.D. Khalkho, S. Jain and A.N. Rai, sp. nov. - Figures 1-3. Mycobank no.- MB 832735

3.1.1 Type: India, Chattisgarh, Jashpur, on living leaves of $B$. monosperma (Lam.) Taub. (Fabaceae), December 2018, leg. Anurag Dubey (Holotype AMH- 10187; Isotype BOT DR 103).

3.1.2 Etymology: New species epithet is derived from the species of host.

\section{Description}

Colonies effuse, light black, hypophyllous, hidden because of large number of trichomes on the lower surface, punctiform. Mycelium superficial, septate, hyaline, branched and smooth. Stroma, Setae and hypopodia are absent. Conidiophores micronematous, mononematous, straight or flexuous, branched, colourless, smooth, length up to $32.79 \mu \mathrm{m}$ and width $1.47-2.95 \mu \mathrm{m}$. Conidiogenous cells monoblastic, determinate, nearly rounded in shape, integrated and terminal. Conidia dark brown to black, may or may not be truncate, simple, acrogenous, globose, mostly rough walled and sometimes smooth walled and 0 septate, $12.78-64.88 \mu \mathrm{m}$ long and $13.27-55.54 \mu \mathrm{m}$ thick.

\section{Discussion and conclusions}

A thorough survey of literature exhibits that A. monospermae sp. nov. is the first species reported on the host genus Butea and its 

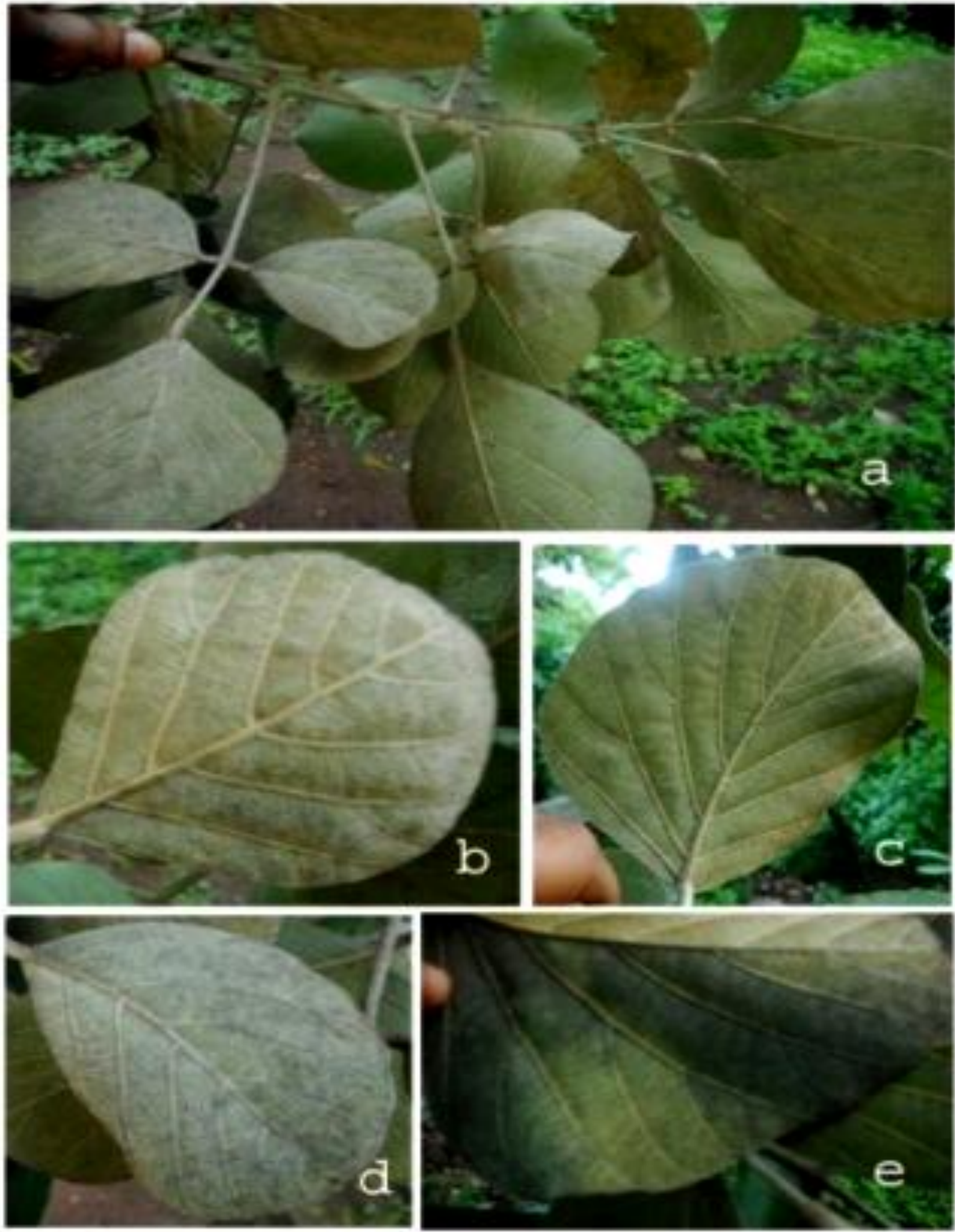

Figure 1 Symptoms of Acremoniula monospermae sp. nov. on Butea monosperma (Holotype AMH-10187). (a.) Infected host plant. (b-c.) Early stage of infection. (d.) Late stage of infection. (e.) Heavy infection. 

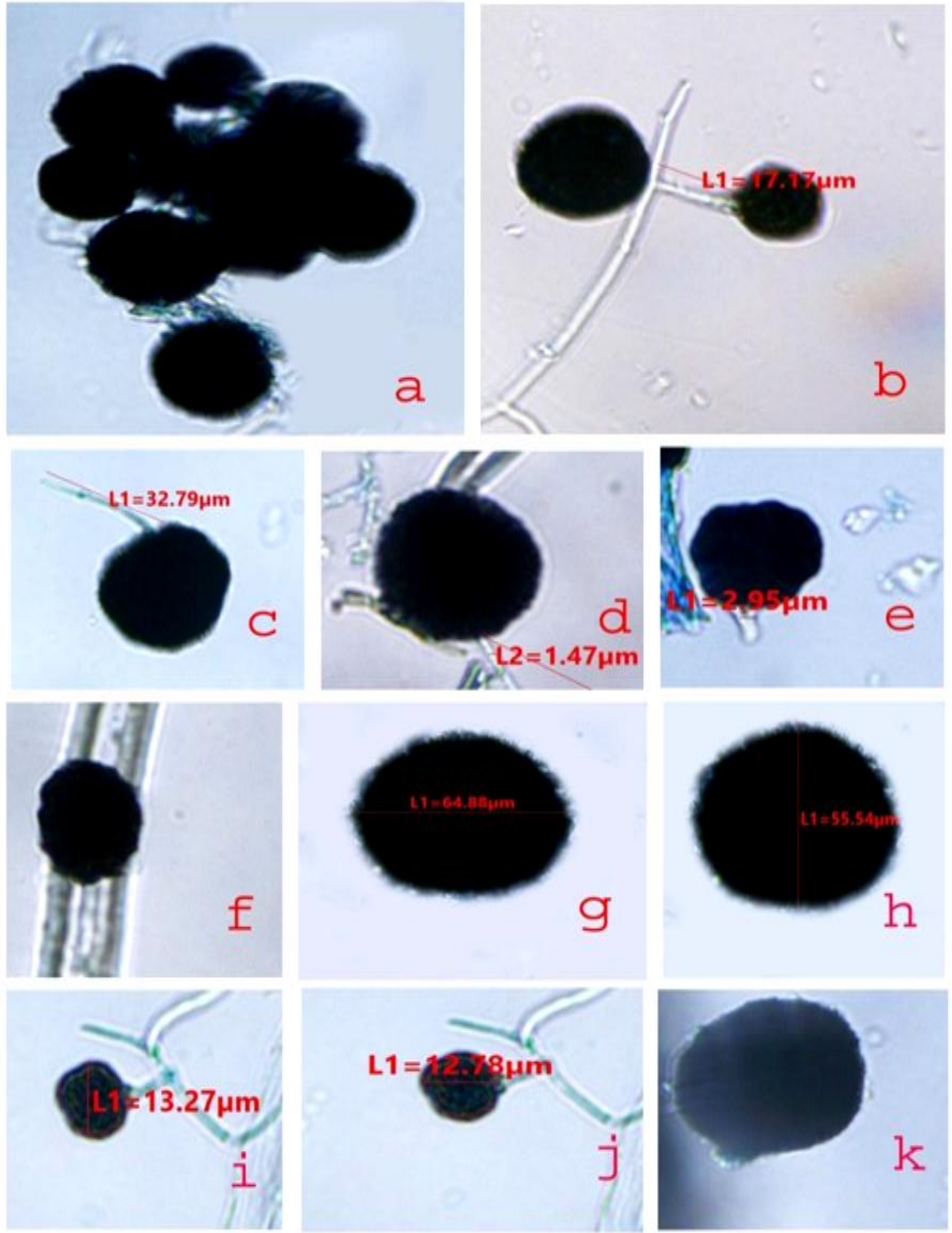

Figure 2 Microphotographs of Acremoniula monospermae sp. nov., (Holotype AMH-10187). (a.) Groups of conidia. (b.) Conidium attached with conidiophore (arising from mycelium). (c-e.) Range of conidiophore dimentions. (f.) Conidia in lumen of trichome. (g-j.) Range of conidial dimensions. (k.) Truncate conidia.

Journal of Experimental Biology and Agricultural Sciences http://www.jebas.org 

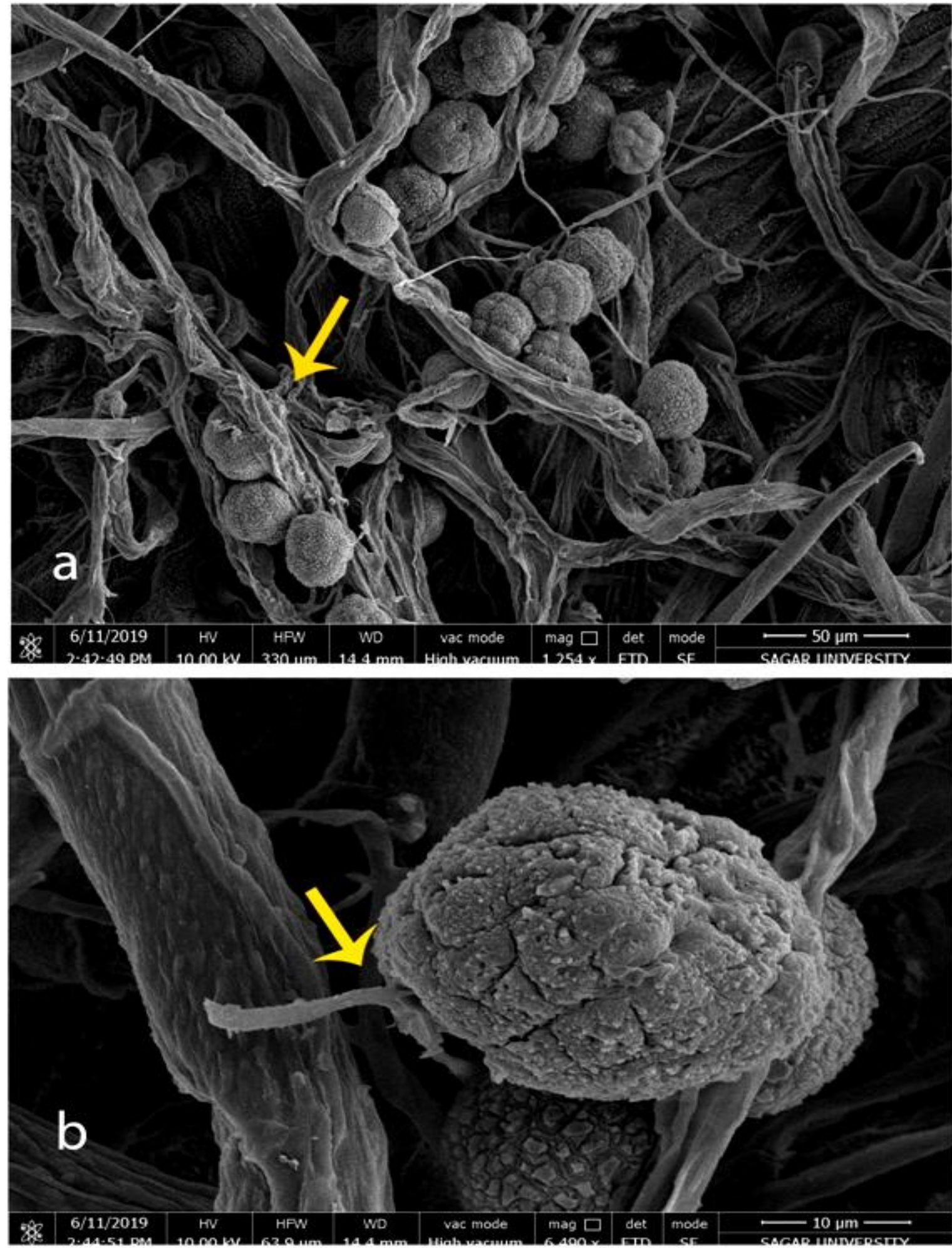

Figure 3 Scanning electron microscopic images of Acremoniula monospermae sp. nov. (Holotype AMH-10187) (a.) Conidia in lumen of trichome (b.) Conidium attached with conidiophore.

Journal of Experimental Biology and Agricultural Sciences http://www.jebas.org 
family. Only seven species of genus Acremoniula G. Arnaud ex Ciferri have been reported from all over world. Among these A. brevis (Hughes, 1979), A. fagi (Ellis, 1976), A. rhamni (Selcuk et al., 2015), A. triseptata (Mercado et al., 1995) and A. uniseptata (Huseyin et al., 2015) are reported as saprophytes while A. sarcinellae (Deighton, 1969) and A. suprameliola (Ellis, 1971) are reported as hyperparasites. However, proposed species of this genus has been reported as parasites for the first time. A critical study, observation, examination and comparison with associated taxa reveal that proposed species shows some similarity with A. fagi (Ellis, 1976) in presence of micronematous and hyaline conidiophores; 0 septate, truncate base and black colored conidia on one hand and have clear cut differences in conidiophores and conidial dimensions. Conidiophore of proposed species are 1.47$2.95 \mu \mathrm{m}$ thick while A. fagi (Ellis, 1976) having more thickened conidiophores $(4-8 \mu)$. A. fagi (Ellis, 1976) having small size conidia (12-17 (14) $\mu$ long and 11-15 (12.5) $\mu$ thick) as compared to proposed species. Acremoniula fagi (Ellis, 1976) is reported on dead branches of Fagus grandifolia while A. monospermae sp. nov. (Holotype AMH10187 ) is clearly present on living leaves of Butea monosperma.

The above Discussion shows that species occurring at new host appeared to be undescribed and new to science i.e. A. monospermae sp.nov. (Holotype AMH-10187).

\section{Acknowledgements}

The authors are thankful to Curator $(\mathrm{AMH})$, Agharkar Research Institute (ARI), Pune, India for deposition and accession number of fungal specimens. The authors are grateful to Head, Department of Botany, Dr. Harisingh Gour University, Sagar, M.P. for providing laboratory facilities. We are immensely grateful to D.F.O and forest staff of Jashpur forest for their help in field survey and UGC for financial support to the senior author (Anurag Dubey).

\section{Conflict of Interest}

The authors declare that they have no conflict of interest.

\section{References}

Awasthi N, Singh R, Kumar S (2015) First report of a foliar disease caused by Cercospora apii s. lat. on Spigelia anthelmia from Madhya Pradesh, India. Schlechtendalia 28: 53-57.

Awasthi N, Singh R, Kumar S (2016) A new species of Pseudocercosporella on Andrographis paniculata from Central India. Sydowia 68: 27-33.

Choedon T, Shukla SK, Kumar V (2010) Chemopreventive and anticancer properties of the aqueous extract of flowers of Butea monosperma. Journal of Ethnopharmacology 129: 208-213.

Das MK, Mazumder PM, Das S, Das S (2011) Butea monosperma (Lam) kuntze: a comprehensive review. International Research Journal of Plant Science 2 : 215-219.

Deighton FC (1969) Some hyperparasitic hyphomycetes and a note on Cercosporella uredinophila Sacc. Mycological Papers 118: 1-41.
Ellis MB (1971) Dematiaceous hyphomycetes. CMI, Kew, England Pp. 57.

Ellis MB (1976) More dematiaceous hyphomycetes. CMI, Kew, England Pp. 36-37.

Hughes SJ (1979) Relocation of species of Endophragmia auct. with notes on relevant generic names. New Zealand Journal of Botany 17: 139-188.

Huseyin E, Selcuk F, Akgul H (2015) Acremoniula uniseptata sp. nov. (hyphomycetes) from Turkey. Jokull 65: 227-230.

Kapoor LD (2005) Handbook of Ayurvedic Medicinal Plants. Herbal Reference Library Edition, Replica Press Pvt. Ltd., India Pp. 86.

Khatak S, Wadhwa N, Malik DK (2019) Comparative Analysis Of Antimicrobial Activity And Phytochemical Assay Of Flower Extracts Of Butea Monosperma And Cassia Fistula Against Pathogenic Microbes. International Journal of Recent Scientific Research 10 : 31285-31290.

Mall TP, Kumar A (2014) Foliicolous fungi: Earths Living Wealth from Shrawasti (Uttar Pradesh), India. International Journal of Interdisciplinary and Multidisciplinary Studies 1: 61-70.

Mercado AS, Heredia G, Mena JP (1995) New species of dematiaceous hyphomycetes from Veracruz, Mexico. Mycotaxon 55: 491-499.

Sabeena A, Hosagoudar VB, Divaharan V (2018) Foliicolous fungi on medicinal plants in Thiruvananthapuram District, Kerala, India. Journal of Threatened Taxa 10: 11470-11479.

Sahare KN, Anandharaman V, Meshram VG, Meshram SU, Gajalakshmi D, Goswami K, Reddy MVR (2008) In vitro effect of four herbal plants on the motility of Brugia malayi microfilariae. Indian Journal of Medical Research 127 : 467-472.

Selcuk F, Huseyin E, Ekici K (2015) A new species of Acremoniula (hyphomycetes) from Central Anatolia, Turkey. Sylwan 159: 444-448.

Thomas J, Alex TE, Thomas RJ (2013) Meliola marthomaensis sp. nov. an addition to Meliolaceae from Western Ghat Region in Kerala State, India. Universal Journal of Plant Science 1 : 100-103.

Tiwari P, Jena S, Sahu PK (2019) "Butea Monosperma: Phytochemistry and Pharmacology". Acta Scientific Pharmaceutical Sciences 3: 19-26.

Tiwari P, Sahu PK (2017) Plants altering hormonal milieu: A review. Asian Pacific Journal of Reproduction 6 : 49-53.

Vaidya A, Pandita N (2017) Comparative Pharmacognostic and Phytochemical Studies of Flower, Leaf and Stem Extracts of Butea monosperma. Asian Journal of Biomedical and Pharmaceutical Sciences 7: 10-18. 